\title{
TEACHING AND LEARNING TOGETHER
}

\author{
COLLEGE FACULTY AND UNDERGRADUATES \\ COCREATE A PROFESSIONAL \\ DEVELOPMENT MODEL
}

\section{Alison Cook-Sather, Bryn Mawr College}

Most models of professional development assume that faculty learning is the purview of faculty colleagues or teaching and learning center staff. A program at Bryn Mawr College challenges that assumption by inviting undergraduate students to serve as pedagogical consultants to faculty members. Feedback from participants suggests that this approach affords faculty and students an unusual opportunity to coconstruct a more informed model of faculty development, deepens the learning experiences of both faculty and students, and recasts the responsibility for those learning experiences as one that faculty and students share.

The vast majority of professional development models assume that either faculty colleagues or the staff of professional teaching and learning centers should be responsible for faculty learning. Reflective and collaborative approaches (Cowan \& Westwood, 2006; Huston \& Weaver, 2008), faculty learning communities (Cox, 2003; Richlin \& Cox, 2004), and peer observation models (Peel, 2005) put faculty into constructive dialogue with one another about what is and what could be happening in their classrooms. With few exceptions (Cox, 2000; Cox \& Sorenson, 2000; Sorenson, 2001;

Many thanks to Jody Cohen, James Groccia, Alice Lesnick, Judith Miller, Elliott Shore, and several anonymous reviewers for helpful comments on the manuscript for this chapter. 
Werder \& Otis, 2010), students are not among the interlocutors or collaborators in faculty learning. Indeed, as Cox and Sorenson (2000) have argued, student involvement "has not only been just a small component of faculty development practices-it has been virtually invisible" (p. 99)

In the Students as Learners and Teachers (SaLT) program at Bryn Mawr College, student involvement is not only visible; it is central to faculty development. College undergraduates assume the role of student consultant and work as partners with college faculty members to cocreate a new model of faculty learning. Part of Bryn Mawr's Teaching and Learning Initiative (www.brynmawr.edu/tli), this program is modeled on a project that positions high school students as consultants to prospective secondary teachers (Cook-Sather, 2002, 2006a, 2009b). Applying to the college context principles of student voice work developed largely within K-12 schools (Thiessen \& Cook-Sather, 2007), SaLT complements a new strand of the scholarship of teaching and learning (SoTL) focused on student voice (Mihans, Long, \& Felten, 2008; Werder \& Otis, 2010).

\section{SaLT: An Overview}

SaLT aims to foster dialogue and collaboration across community members who occupy traditionally distinct and delineated institutional roles (Lesnick \& Cook-Sather, 2010). Specifically, SaLT aims to support generative dialogue about teaching and learning that rarely unfolds between faculty members and students and, through that dialogue, to affirm and improve teaching and learning in the college's classrooms. Funded by a grant from the Andrew W. Mellon Foundation, SaLT has run every semester since its pilot in spring 2007. It is neither formally evaluative nor intended to be remedial, and faculty involved choose to participate for a variety of pedagogical reasons. Students too participate for various reasons, but all of them desire to be part of a reflective dialogue about what is happening and what could be happening in college classrooms.

Each year all faculty members at Bryn Mawr and Haverford Colleges are invited to apply to participate in a semester-long seminar that includes weekly two-hour meetings, weekly posts to a closed blog, work with a student consultant, mid- and end-of-semester feedback, and development of a final portfolio or a stand-alone partnership with a student consultant that can last anywhere from several weeks to a full semester. One of the seminars is devoted to supporting incoming tenure-track faculty members, who are given a course release by Bryn Mawr and Haverford provosts for their participation. Three other seminars, each with five spaces, are open to all full-time, continuing faculty members, who earn stipends for their 
participation that are supported by the Mellon grant. Faculty applicants go through a lottery process; those who are selected are assigned student consultants largely according to participants' schedules and, where possible, taking into consideration style and personality. Between 2007 and 2010, SaLT supported eighty-nine faculty members and thirty-nine student consultants in 115 partnerships. Faculty span ranks and divisions range from new to the colleges to those with forty years of teaching experience.

Sophomore through senior students enrolled as undergraduates at Bryn Mawr and Haverford are invited to apply for the role of student consultant. Applicants include students who major in different fields, claim different identities, and bring varying degrees of formal preparation in educational studies (from those with no course work in education to those pursuing state certification to teach at the secondary level). The application process includes writing a statement regarding their qualifications and securing two letters of recommendation-one from a faculty or staff member and one from a student. Student consultants attend an orientation and are supported in their work through weekly reflective meetings.

Students are not enrolled in the courses for which they serve as consultants. Each student consultant has the following responsibilities: meet with the faculty member to establish why each is involved and what hopes both have for the collaboration and to plan the semester's focus and meetings; visit one class session each week; take detailed observation notes on the pedagogical challenges the faculty member has identified; survey or interview students in the class (if the faculty member wishes) for midcourse feedback or at another point in the semester; meet weekly with the faculty member to discuss observation notes and other feedback and implications; participate in weekly meetings with one another and with me in my role as the coordinator of SaLT; and visit one or more faculty seminars five times over the course of the semester. For full-semester partnerships, student consultants work approximately seven hours per week and receive nine hundred dollars. For shorter partnerships, student consultants are paid by the hour.

Both student consultants and faculty members receive handbooks that I revise each semester with input from experienced student consultants and faculty participants. The handbooks outline the key commitments of the SaLT program and, rather than strict prescriptions for practice, offer guidelines for building partnerships.

In addition to the formative assessment conducted throughout the partnerships, at the conclusion of each partnership, all participants answer a series of questions such as, "What are the most important insights, lessons, affirmations, new understandings, and clarifications you 
take forward with you from this experience?" These questions provide participants an opportunity to revisit issues they explored together during their partnerships and provide essential feedback to me as program coordinator.

\section{Challenging the Norms of Professional Development}

Norms within professional development include neither the premise that students have unique perspectives on learning and teaching and should be afforded opportunities to actively shape their education (Cook-Sather, $2006 \mathrm{~b})$ nor the premise that we have "an ethical obligation to involve our students more actively [in faculty development]" (Zahorski, quoted in Cox \& Sorenson, 2000, p. 98). Therefore, both faculty and student participants must wrestle with the doubts and vulnerabilities prompted by these premises. Faculty must rethink their customary position of authority on pedagogical practice. In one faculty member's words, "There's a need to overcome something that I would have thought had I not heard [their] thoughtful comments: What do students know?" (All quotations included are representative of a perspective shared by at least three participants.) Students must overcome their usual posture of deference to faculty authority. One student explained: "I was hesitant about my ability to do a good job given my lack of background in education, and given that I am just a student."

Regardless of their ascribed authority or lack thereof, both faculty members and students feel vulnerable as they enter into this new partnership. One student consultant explained, "At first I was kind of skeptical because you are a student and these profs have been doing this for quite some time; they have advanced degrees-you're a kid with some college. And you are trying to come in and say, 'Do this better, do that.' You could easily be dismissed." Faculty members also express apprehensions. About the experience of having a student of color serve as a consultant focused on creating a more culturally responsive classroom, one faculty member said, "On the one hand, I felt that she had a certain legitimacy as an informant, but it also made me feel more exposed-that she would be able to see all the things that were problems."

Working together, faculty and students not only overcome their uncertainties but also enthusiastically embrace the notion of students as colleagues in analyzing classroom practice. Explained one faculty member, "I wondered if our students can do the same things as a professional teaching and learning center, but I'm a convert." Another faculty member asserted, "It's more effective to have a student come in rather than a 
colleague. We look for something different than a student looks for." And a third went further to assert that "by listening to our students, especially in institutions that claim students as colleagues, we can start to fulfill the claims that we make as educational institutions."

By challenging the norms of professional development through inviting students into dialogue with faculty members about classroom practices, SaLT works toward "radical collegiality" in which students are "agents in the process of transformative learning" (Fielding, 1999, p. 22). Faculty and students engage in "a significant reciprocity" through which teachers learn "with and from young people ... through processes of coconstructed, collaborative work" (Fielding, 2006, p. 311). By affording faculty the opportunity to engage in a richer, more variously informed version of reflective practice (Cook-Sather, 2008), SaLT reconceptualizes faculty learning as part of an ongoing and unending process of dialogue and revision with those usually on the receiving end of pedagogical practice: students.

\section{Cocreating a New Model of Professional Development}

SaLT requires deliberate and intentional coconstruction of the facultystudent partnership. This work includes affirming reciprocal interest and respect, identifying pedagogical goals, and finding a language and a mode through which faculty and student consultants interact with one another in order to build confidence and support revisions of practice. Faculty members must assure student consultants that they are open to and interested in what the consultants have to say. Likewise, student consultants must assure faculty members that they are supportive and affirming as well as constructively critical.

Because the goal of this work is faculty learning, faculty members must work to identify and articulate what they want the focus of the work to be and find a good balance between maintaining their existing pedagogical commitments and developing as teachers. One faculty member appreciated "the opportunity to first articulate to myself [and then to my student consultant] what I want to happen in the classroom." Through such dialogue, according to another faculty member, it is possible to clarify and better pursue one's pedagogical commitments. This faculty member explained: "[My student consultant] alerted me to the students' confusion resulting from my style of questioning. ... Her presence in the classroom made me more aware of how I presented myself in the class and how I 'read' the students and my patterns of interaction with them. Her suggestions enabled me to broaden and diversify patterns of interaction." 
While faculty members need to clarify and articulate their pedagogical commitments to both themselves and student consultants, the challenges student consultants face include balancing diffidence with authority, building their confidence, and developing a language with which to offer feedback. Both the premises and structure of the SaLT program "really enhanced my confidence," one student consultant explained, "in the fact that I can do this job and that I have competence in this area." Another student consultant reflected: "It was so nice to think I had a perspective [the professor I was working with] hadn't thought about. And then she would say things I hadn't thought about. So it challenged both of us." Building on the confidence they develop, student consultants learn how to offer feedback in constructive ways. They consistently use phrases such as, "In my own experience as a student" or "If I were a student in this class, I would feel ..." Such formulations allow professors to hear and receive what student consultants have to say.

If faculty members are not as deliberate, intentional, and careful as they might be in inviting students into this partnership, students can have a hard time developing the confidence they need to support faculty learning. One consultant contrasts experiences with two different faculty membersone in which she felt her efforts to engage in productive dialogue were thwarted and one in which they were embraced: "This time around, because of the way he was reacting to my feedback, I really felt like my role was indeed changing and I wasn't just a student - that I came with a perspective and expertise of a student but that was just as valid as the things he was bringing to the table (as opposed to last time I felt like I was still the little student and he was the big teacher)." This dynamic works both ways: if students are not as deliberate, intentional, and careful as they might be in establishing a partnership with their faculty partners, faculty members can feel too vulnerable to benefit from the partnership.

When both faculty and students achieve a productive balance between affirmation and challenge and navigate their relationship respectfully and responsibly, they develop a "generative and creative" partnership, as one faculty member explained, that allows them "to move in and out of the roles" that they generally occupy. They experience, as one student consultant put it, "teaching and learning as collaboration between all parties involved."

Both the perennial pedagogical challenges that all faculty members face and the process through which they might explore those challenges appear less daunting when faculty members engage with students in constructive dialogue about teaching and learning. As one faculty member explained: "In this project there's some recognition on the part of everyone that 
nobody's the expert, so you just say what you think. I may choose to believe you or not believe you, but there's not a right answer that you are charged with coming up, no magical solution. You're providing your perspective ... it's just a conversation, part of a process."

Student consultants also emphasize the dialogical nature of the relationship and the fact that the partners are engaged in an ongoing problemsolving rather than a solution-finding process: "[My faculty partner is] being really receptive to my ideas and we're having a lot of dialogue about ways to generate new, not solutions, but things to try out in the classroom and see how they work." Such a model of faculty learning supports the development of teachers who can communicate, learn, and change, and it supports pedagogy that is always evolving in practice and as a focus of analysis.

\section{Deepening Faculty Learning}

Among the wide variety of lessons learned from their work with student consultants, faculty most often identify the importance of the following two: gaining a student perspective on one's practice and expanding strategies for engaging students.

Faculty members highlight the literal fact that a student consultant "has a line of sight into the space of the classroom which I do not have from where I stand." One faculty member offered a vivid illustration of what this new angle of vision affords:

There are some quiet students in my class-this was really powerful for me-one student was putting up her hand very slightly. I was literally blind to her. [The student consultant] pointed it out. Then [the student] did it next class, and I saw her, and she talked three times. When [the student consultant] told me, I was stunned-I had just missed her. And when she did talk, she said very thoughtful things.

A student consultant's angle of vision opens up space that faculty members cannot see on their own. Through the dialogue in which the faculty-student partners engage, the student's angle of vision also informs faculty thinking about what can happen in that space. One faculty member described her dialogue with her student consultant as "an ongoing intercambio [exchange] in which I was able to get a sense of how others experience the class." She explained that because of this dialogue, "rather than always privilege what worked for me as a student, I work to draw out how different pedagogical practices [and] learning styles can illuminate the space of a classroom for all those around the table." 
The perspective and insights faculty members gain through working with student consultants not only enhance their teaching while they are in the partnerships but also shape their subsequent thinking and practice. One faculty member said:

I like that her presence-her comments, but her presence itself toonot only gives me the benefit of her lighthouse-like observations, but makes me observe from the same kind of remove, even as I am engaged in the everyday work of teaching the class. This split experience of my class as an immediate act and experience, but also a larger narrative that I'm looking down upon, is something I hope to carry into all my teaching.

Using a different metaphor, another faculty member explained: “The student consultant voice remains in my head during lectures [and] discussions and I am trying to rethink my presentations or view them from a student perspective while talking."

In part because they come to value the student perspective and think more deeply about the student experience, faculty members explore several ways to engage students, including making expectations clear and explicit, supporting the development of students' metacognitive awareness, and creating opportunities for students to be more active in and more responsible for their learning. Supporting her claim that her teaching "improved a lot" through her participation in SaLT, one faculty member captured succinctly the importance of making expectations clear and explicit: "I've become more comfortable balancing elements of my teaching style with what students need; for me, this means being rigorous in my expectations for students, but making those expectations extremely clear."

Being explicit about expectations is closely related to another strategy faculty members identify: supporting the development of students' metacognitive awareness-their awareness of their learning and their approaches such that they can make informed and intentional decisions about those. In part because they develop their own metacognitive awareness through the various forums for reflection and dialogue provided by SaLT, and in part because their student consultants emphasize its importance, faculty members deliberately construct activities to support the development in students of metacognitive awareness. As one faculty member put it:

For most students, metacognition does not just happen-in fact, students are probably unaware of what it is! There is little chance of 
developing metacognitive habits if they do not know that they need to do so! Thus, the purpose of [the metacognitive exercises I developed] is not only to help their immediate understanding and my immediate awareness of their understanding, but also (if I tell them so!) to model the metacognitive habits that I hope they cultivate.

Related to the development of metacognitive awareness is the importance of creating opportunities for students to be more active in and more responsible for their learning. Building on the practice of gathering midsemester feedback supported by SaLT (Cook-Sather, 2009a), one faculty member explained: "I've started using midsemester course feedback in order to get a sense of what is engaging for students, what might be standing in the way of full engagement." Another faculty participant stated: "I'm constantly trying to think of ways I can put the pedagogical goals I have for my students in their hands."

\section{Deepening Student Learning}

Students who take on the role of student consultant consistently report two ways in which their learning is deepened and expanded. They repeatedly describe becoming better learners and assuming more agency in and taking more responsibility for their education.

Bain and Zimmerman (2009) point out that the most successful students are deep learners, meaning those who are concerned with understanding how to apply their ideas to consequential problems, implications, and ideas and concepts. Such learners are likely to "theorize and make connections with other ideas and problems ... [and] . . . to become adaptive experts who both recognize and even relish the opportunity and necessity for breaking with traditional approaches and inventing new ones" (p. 10). Student consultants suggest that they develop these capacities in their role. One claimed: "I think that this project has helped me a lot in thinking about myself as a student, what works best for me, and how to work within a structure that a professor has set up to get the most learning out of the experience." Another stated: "I am a much more conscientious student in general now; I ask myself what I could do differently to improve my own classroom experience, rather than complaining about the professor or the course in general."

These increased capacities contribute to the second change that student consultants describe: the ways in which they take more responsibility for their own and others' education (Cook-Sather, in press) and feel they have greater agency in that education. One student consultant wrote: "As a 
learner, I will be a student who goes after what I want in terms of learning. I won't be afraid to talk to profs if I have issues 'cause I know from this experience that they are open to suggestions, they try to help students get as much as they can out of the course." Another said: "In past discussions I've always been talking about what the profs do to us and it's been a oneway street. And now I am able to look at it as a relationship in the classroom; if we're complaining about something that is going on, it's also the students' role to step up and say something about that."

\section{Sharing the Responsibility for Learning in College Classrooms}

By working together to cocreate this form of professional development and deepening their respective learning experiences as a result, both faculty and students begin to see the responsibility for exploring and improving teaching and learning as shared. One faculty member explained: "I work with students more as colleagues, more as people engaged in similar struggles to learn and grow. I have become even more convinced that students are experts in learning and essential partners in the task of creating and developing new courses and refining existing ones." Another faculty member put it this way: "It doesn't mean that you are giving over control of the course. But there are elements of the classroom that we are coresponsible for, that we are traveling through together."

Student consultants made similar statements regarding the shared responsibility that can emerge from this work: "Students are working with faculty to build courses, to build their learning experience" (Cook-Sather, 2009a, p. 237). Another student clearly stated the shared responsibility she feels for teaching and learning: "This experience has made me increasingly alive to both the professor's perspective and to my own responsibilities as a student in creating and maintaining a positive and effective learning environment for all members of the class." And a third named education as the whole college community's responsibility: "It is up to the entire community to make learning spaces function, so that means students have just as much responsibility as professors."

\section{Recommendations for Faculty Developers}

Our three years of experience with the SaLT program have suggested some recommended guidelines for those who are considering starting a similar program. 


\section{Consider Your Context, and Invite Participant Input}

Take into consideration the size and type of your institution as well as the nature and commitments of faculty members and students. With these in mind, design forums and guidelines that will speak to potential participants. In both the creation and the evolution of the program, invite participant input, and, as Cox (2000) has emphasized as well, monitor participant experiences and adjust accordingly.

\section{Create Liminal and Confidential Spaces}

Create spaces for faculty learning that are not part of the administration or any particular department (Cook-Sather \& McCormack, 2010). Liminal spaces open up possibilities that likely remain closed off when community participants stay in their accustomed locations (Cook-Sather \& Alter, 2010). Finally, do not link faculty work within the program to review for reappointment or promotion, and, as Sorenson (2001) has indicated, make sure that participants preserve confidentiality.

\section{Make Participation Voluntary and Faculty Driven}

Beyond inviting participant input into the design and evolution of the program, it is essential that both faculty participants and student consultants choose to participate. Furthermore, faculty members, at least initially, should identify the focus of their work with student consultants. This work requires risk, but as one faculty member put it, "This project is making a safer place to be vulnerable and thus learn and grow and be out of your shell." When faculty members feel safe enough to risk learning, they are much more likely to invite both student consultants and students in their classes into dialogue about and collaborative revision of teaching and learning.

\section{Bring Differently Positioned Participants into Structured Dialogue}

The forums, guidelines, and facilitation that comprise the SaLT programhandbooks, weekly meetings, reflective assessment questions, active and engaged support by the program facilitator-both affirm and challenge participants to think critically, take risks, and develop new ways of talking with one another about teaching and learning. With such structured support, participants can build enough trust to talk honestly across differences of role and status about the work of education that they share. 
Faculty and students open themselves to perspectives and insights they cannot achieve from their own angles of vision and are inspired to act on what they see.

\section{Recognize This Work as Ongoing}

Freire (1998) argued that it is our unfinishedness that makes us educable. Affording faculty members opportunities to engage in well-supported, ongoing learning opportunities both accelerates their learning (CookSather \& McCormack, 2010) and reminds faculty that learning is a lifelong process. Including students among those responsible for teaching and learning in college classrooms extends Shulman's (2004) call to make teaching "community property" and thus affords both faculty members and students an opportunity to deepen their own learning in their respective roles and build a stronger, richer educational community for which both groups share responsibility.

\section{REFERENCES}

Bain, K., \& Zimmerman, J. (2009). Understanding great teaching. Peer Review, 11(2), 9-12.

Cook-Sather, A. (2002). Authorizing students' perspectives: Toward trust, dialogue, and change in education. Educational Researcher, 31(4), 3-14.

Cook-Sather, A. (2006a). Education is translation: A metaphor for change in learning and teaching. Philadelphia: University of Pennsylvania Press.

Cook-Sather, A. (2006b). Sound, presence, and power: Exploring "student voice" in educational research and reform. Curriculum Inquiry, 36(4), 359-390.

Cook-Sather, A. (2008). "What you get is looking in a mirror, only better": Inviting students to reflect (on) college teaching. Reflective Practice, 9(4), 473-483.

Cook-Sather, A. (2009a). From traditional accountability to shared responsibility: The benefits and challenges of student consultants gathering midcourse feedback in college classrooms. Assessment and Evaluation in Higher Education, 34(2), 231-241.

Cook-Sather, A. (2009b). Learning from the student's perspective: A sourcebook for effective teaching. Boulder, CO: Paradigm.

Cook-Sather, A. (in press). Students as learners and teachers: Taking responsibility, transforming education, and redefining accountability. Curriculum Inquiry.

Cook-Sather, A., \& Alter, Z. (2010). What is and what can be: How a liminal role changes college students' educational experiences and expectations. Manuscript submitted for publication. 
Cook-Sather, A., \& McCormack, E. (2010). Recurrence and repositioning: Keys to supporting teaching excellence in the liberal arts college. Manuscript submitted for publication.

Cowan, J., \& Westwood, J. (2006). Collaborative and reflective professional development: A pilot. Active Learning in Higher Education: The Journal of the Institute for Learning and Teaching, 7(1), 63-71.

Cox, M. D. (2000). Student-faculty partnerships to develop teaching and enhance learning. In J. E. Miller, J. E. Groccia, \& M. S. Miller (Eds.), Student-assisted teaching: A guide to faculty-student teamwork (pp. 168-171). San Francisco: Jossey-Bass/Anker.

Cox, M. D. (2003). Proven faculty development tools that foster the scholarship of teaching in faculty learning communities. In C. M. Wehlburg \& S. Chadwick-Blossey (Eds.), To improve the academy: Vol. 21. Resources for faculty, instructional, and organizational development (pp. 109-142). San Francisco: Jossey-Bass/Anker.

Cox, M. D., \& Sorenson, D. L. (2000). Student collaboration in faculty development. In M. Kaplan (Ed.), To improve the academy: Vol. 18. Resources for faculty, instructional, and organizational development (pp. 97-106). Stillwater, OK: New Forums Press.

Fielding, M. (1999). Target-setting, policy, pathology and student perspectives: Learning to labour in new times. Cambridge Journal of Education, $29,277-287$.

Fielding, M. (2006). Leadership, radical student engagement and the necessity of person-centred education. International Journal of Leadership in Education, 9(4), 299-314.

Freire, P. (1998). Pedagogy of freedom: Ethics, democracy, and civil courage (P. Clarke, Trans.). Lanham, MD: Rowan \& Littlefield.

Huston, T., \& Weaver, C. L. (2008). Peer coaching: Professional development for experienced faculty. Innovative Higher Education, 33(1), 5-20.

Lesnick, A., \& Cook-Sather, A. (2010). Building civic capacity and responsibility through a radically inclusive teaching and learning initiative. Innovative Higher Education, 35(1), 3-17.

Mihans, R., Long, D., \& Felten, P. (2008). Student-faculty collaboration in course design and the scholarship of teaching and learning. International Journal for the Scholarship of Teaching and Learning, 2(2). Retrieved from http://academics.georgiasouthern.edu/ijsotl/v2n2.html

Peel, D. (2005). Peer observation as a transformatory tool? Teaching in Higher Education, 10(4), 489-504.

Richlin, L., \& Cox, M. D. (2004). Developing scholarly teaching and the scholarship of teaching and learning through faculty learning communities. In M. Cox \& L. Richlin (Eds.), New directions for teaching and 
learning: Vol. 97. Building faculty learning communities (pp. 127-135). San Francisco: Jossey-Bass.

Shulman, L. S. (2004). Teaching as community property: Putting an end to pedagogical solitude. In L. S. Shulman, Teaching as community property: Essays on higher education (pp. 140-144). San Francisco: Jossey-Bass. Sorenson, L. (2001). College teachers and student consultants: Collaborating about teaching and learning. In J. E. Miller, J. E. Groccia, \& M. S. Miller (Eds.), Student-assisted teaching: A guide to faculty-student teamwork (pp. 179-183). San Francisco: Jossey-Bass/Anker.

Thiessen, D., \& Cook-Sather, A. (Eds.). (2007). International handbook of student experience in elementary and secondary school. Dordrecht, Netherlands: Springer.

Werder, C., \& Otis, M. M. (Eds.). (2010). Engaging student voices in the study of teaching and learning. Sterling, VA: Stylus. 